International Journal of Linguistics Studies (IJLS)

ISSN: 2754-2599

DOI: $10.32996 / \mathrm{ijls}$

Journal Homepage: www.al-kindipublisher.com/index.php/ijlss

\title{
IJLS
}

\section{Critical Discourse Analysis of Pakistani Foreign Minister Qureshi's Speech at UN in 2021: A Sociopolitical Perspective}

\author{
Ali Furqan Syed ${ }^{1} \square$ Muhammad Junaid $^{2}$, Muhammad Usman Haider ${ }^{3}$, Rabia Hashim ${ }^{4}$ and Muhammad \\ Akram Khan ${ }^{5}$ \\ ${ }^{1}$ Lecturer, Department of English, University of Sialkot, Sialkot, Pakistan \\ ${ }^{2345}$ MPhil Scholar, Department of English Language and Literature, The University of Lahore Sargodha Pakistan, Pakistan
}

$\square$ Corresponding Author: Ali Furqan Syed, E-mail: ali_syed786@yahoo.com

\begin{abstract}
ARTICLE INFORMATION
Received: 08 September 2021

Accepted: 11 October 2021

Published: 16 October 2021

DOI: $10.32996 /$ ijls.2021.1.2.4

KEYWORDS

CDA, social inequalities, political conflict, dominance, discrimination

\section{ABSTRACT}

This paper is based on the Critical Discourse Analysis approach to explore Pakistani Foreign Minister Shah Mehmood Qureshi's speech at the UN in 2021 in a sociopolitical context. The researchers, by applying Fairclough's 3D model, investigate Arab Israel community reflection through textual or stylistic strategies in speech and explore the level of Islamic ideology reflected in Shah Mehmood Qureshi speech through linguistic choices. The study further explores the representation of stylistic features in a speech that depicts the political and socio-cultural relationship between Palestine and the Israeli community. Findings of the study suggest that Foreign Minister Shah Mehmood Qureshi used different devices like textual and stylistic to give his ideology more explicatively. The sophisticated manners of ideology are propagated through the speech with all its prerequisites. It was syntactically well organized and produces a thematic message that was based on religious sociocultural and political discrimination and biased as well as inequality in cohesion. The expressive speaker values and relational indications were ordered according to the situation.
\end{abstract}

\section{Introduction}

There are multiple definitions of the term discourse. Discourse is the study of language, which usually deals with the usage of language and its patterns; those are not only acceptable in that particular community but also used in different forms. Discourse is an umbrella term with a number of definitions. Richter et al. (1988) state that discourse "integrates a whole pallet of meanings". But the meaning of that text always originates from linguistics. Oneself is verbally expressed by discourse. Discourse is a way to understand experience and value in the world. To normalize the world, the discourse that is built on everyday context is exercised to build knowledge and power for hegemony to regulate the progression of new knowledge.

People who live in a particular area and have similar conversions and share common beliefs and values deal with the subject of discourse analysis. The analysis is basically dealing with the analysis of every part of a whole. When we talk about discourse analysis, it means it is the analysis of written text as well as spoken words in a particular way using specific tools. The social context of language use is the main focus in discourse analysis. This article presents Shah Mehmood Qureshi's speech for critical discourse analysis using the 3D Model of Fairclough.

In a social relationship, the overt, as well as covert inequalities of power and hegemony, are uncovered in specific discourse by using political discourse and institutional discourse in the usage of language that is specifically considered in critical discourse analysis. When language is produced in the form of speech or writing and the context in which a social structure, institution, situation, or specific discursive event establishes a dialectical relationship between them (Fairclough and Wodak, 1997), it becomes

Copyright: (c) 2021 the Author(s). This article is an open access article distributed under the terms and conditions of the Creative Commons Attribution (CC-BY) 4.0 license (https://creativecommons.org/licenses/by/4.0/). Published by Al-Kindi Centre for Research and Development, London, United Kingdom. 
social practice. So, discourse is not only socially constitutive but also shaped by it through this double-edged relationship of social connection.

The influence of discourse is such that it cannot only produce but also reproduce the power relations of inequality between dissimilar professional groups, ages, genders, social classes, and ethnicities. In the Critical Discourse analysis of the selected speech of the Pakistani foreign minister, the relationship between language and power is highlighted. It points out how Shah Mehmood Qureshi, in front of the UNSC, challenged the powerful nations of the world. Through CDA, the speech's persuasive nature is closed by him. Through his speech, Shah Mehmood Qureshi urges the representatives of the world to show their responsibility against apartheid and racial, social, and religious discrimination against Palestine.

\subsection{Research Questions:}

1. How is the Arab Israel community reflected through textual or stylistic strategies in Qureshi's speech at the UN?

2. To what extent the Islamic ideology is reflected in Qureishi's speech at UN?

3. How do stylistic features in the speech depict the political and socio-cultural relationship between Palestine and Israeli community?

The questions have worth conducting research to highlight the attitude of powerful Nations with the Israeli and Palestine with the help of language. Also, the researcher also wants to highlight the ideology and theme of speech for the Palestinian people who are socially and politically oppressed to represent the Palestinian perspective, the speaker used metaphors as stylistic devices that the research will analyze. Political and socioeconomic perspective was used at the wider lever to analyze the power relation.

\section{Literature Review}

Particularly CDA deals with any discourse analysis. In a society, discursive practices like racial discrimination, basic rights inequality domination hegemony deals with this perspective whether it is in the form of written or spoken. CDA focus on the analysis of political and socio-economic practices and in the exertion of them in society (Vandijk, 1998a).

In CDA, different social and ethnic groups are bought together in an odd relationship for the discourse analysis. Fairclough put his major focus on text and events that happen in a sequence. He relates them with those practices that how power relations were shaped by ideology and inequality. And how the people's discourse in the perspective of social and cultural sense relates with CDA. He also explores that how elite class text based on their ideology and attitude of hegemony is used in the exercise of power (Fairclough, 1993).

According to Fairclough (1992), discourse analysis has three stages. In CDA the first stage deals with the speaker's knowledge and his personal experiences while taking into consideration his beliefs. In the second stage, CDA looks at how discourse is affected by social relations. The third stage of CDA deals with the realization of speakers about identity and reality about certain phenomena. According to him the speaker's identity and social background could be revealed by his syntactic pattern and lexical selection. In discourse, these are linguistic choices for particular contexts to convey specific messages. He argues that in power relation exertion the discourse shaped by language and socio-political has a leading role.

Different people of the same group in a specific setup by their speeches show different expressive norms and relations. So, according to this between linguistic and social variables, there is a strong connection. So the political process and functions of ideologies in the language in social theory have the main concern in the text analysis in CDA. This is the prime purpose of CDA (Fairclough, 1992).

Brown and Yule's (1985) language does not deal in the description or explanations. It also has its "doing" phenomenon. Language is also used for doing things in real life. In CDA language is used for ethnic and social history and to reveal the culture and for context reality. In his view, the speaker's socio-cultural background could be revealed through language presentation syntactically and lexically. Because the choice of words describes the context of a specific phenomenon, the binary relations of discursive practices are reflected through their language and how that language was used is analyzed in CDA.

In a social setup while communicating people act accordingly so the language is a social act. In communication language and society are not directly linked but everyone is dependent on the other one. Our identities are constructed by language and context is also constructed in the same way. English is the language of dominant people so the people who speak this language fluently are considered dominant culturally and socially. So, according to this the particular class with a specific linguistic variable has a specific linguistic identity that describes his position in society (Halliday, 1978). 
According to Halliday (1971), the link between language and situation is built by language itself. When a speaker or writer produces text in written or oral form and it is recognized by the reader or listener.

According to Fairclough (1995b), the intertextual analysis is done in the background of the socio-cultural perspective. It is the discourse practice of linguistic analysis. So, when the analysis is done at vocabulary, grammatical, syntactic, and lexical levels, it is called linguistic analysis. This analysis also includes cohesion coherence of the text with respect to the organization. All discourse practices have greatly emphasized text for this analysis.

According to Fairclough (1992), the text that contains the chunks of any other text and makes it as a whole this characteristic of text is called intertextuality. The other text completely resolves in the original text and the idea that the original text has could be accepted or refuted by that text. Intertextuality can be divided into two main types the first one is "manifest intertextuality" and the second one is "constitute intertextuality". When we talk about the "manifest intertextuality" these deal with the original text that we put as it is in the main text while using quotation marks. The argument is authenticated and validated through this process. And the second form is a little bit different in this type of intertextuality. The new text is produced by keeping the same idea in someone's own work. Through linguistic analysis, the analysis of this kind of text could be done according to Fairclough.

Fairclough (1989) explains that in textual analysis the perspective of his approach is "critical language study". In a society, the use of language helps the hegemonic powers for the exploitation of rights through the discursive practices of society and social relations. He basically put his emphasis on the exploration of those discrimination to unfold them. In his view, in a hegemonic society, power is exercised through language. To exert dominance people, use their language to dress them though in the form of text.

According to Fairclough (1989) "I shall use the term discourse to refer the whole process of social interaction of which a text is just a part". He says that text is less intensive than discourse.

Wodak and Fairclough $(1995 a, 1996)$ describe that in a society, language is used to create dominance, power, and hegemony. In a society like a mirror, the social practices are reflected through language. The hegemonic attitude of the director is revealed through the linguistic choice that he makes while talking to the peon or clerk so the same company. In the company, the way of communication that director use while talking to his employees reveal his social relation that how different types of language is used with the member of the same society having different positions. The text meaning is also based on history so the vital role is played by discourse through historical perspectives. Every text in a particular context has a different meaning that could be clarified through context by concerning specific historical perspectives.

According to Gee (1990) and Sampson (1980) argues that through various approaches, discourse is interpreted systematically by CDA but the economic and socio-political context has its major influence on that. In the discourse interpretation, the significant role is played by social semiotics because in a particular context the analysis of the social factors could be done.

Fowler (1996) the background of the discourse like political economic and social should be represented through the CDA perspective by the critique. According to him, the CDA perspective deals with the production of knowing and exploitation knowledge to increase the consciousness of people to view the socio-cultural context of discourse. He says that discourse criticism instead of critical orientation should not be focused on the representation of analysis.

Corson (1995) argues that certain techniques are applied in critical discourse analysis, like social relation, which is highlighted through stylistic and textual features, and through linguistic perspective we find identities. Through text, social issues like dominance and hegemony are reflected. The text analysis in the education system like an official document of schools is also done through discourse.

According to Blommaert (2005) and Jorgensen (2002), the impact of language in discourse and the impact of language within society have a great impact on them. the analysis of this language relation is wider and broader that is done through critical discourse analysis. In CDA research, the linguistic and social variables in interlinked with each other in a knitted form. The discursive practice context is analyzed through socio-political context it is when we try to find that how language choice is used in specific linguistic perspectives.

Chilton (1996) and Lakoff (1995) state that in critical discourse analysis the significant role is played by metaphors. The ideology is represented through metaphors in discourse. These metaphors explain the individual perceptions regarding a particular context of reality. Shah Mehmood Qureshi used some metaphors in his speech at UNSC and through these metaphors, he reflected the sociocultural background of his ideology. 
According to Hu Zhanglin, (1988) the mechanisms of language have the ability to produce a discourse of written or spoken into a unified and coherent text from arbitrary sentences in the formation of living passage. It is possible that two-sentence that have textual coherence dissimilar may have the same ideology or interpersonal function.

Van Dijk (1993), states that media and politics are interlinked because the elite class ideologies and thoughts are propagated through media. He states that through media elite class not only advocates his ideology but also retains it. Through media, they exploit others and maintain their hegemonic powers.

Ruth Wodak (2001) and Meyer (2001) give the interpretation of the term "Critical in critical discourse analysis they also elaborate on the economic, political, and social perspective embedded in language. In a socio-political context at a wider level language is used in the exertion of power to develop the connection through CDA between language and power. Through social relations, the construction and production of identities and ideologies are reflected through the text primitively. They argue the through CDA in social practices the power relation is not only traced but also they have chances to criticize or challenge these power relations in society.

Carroll (2004) argues that for text or speech analysis several dimensions are provided by critical discourse analysis. It describes that how to analyze the data or method and theory or theoretical framework as a function. For discourse analysis, the perspective of sociology and postmodernism have significant importance in critical discourse analysis. In social relations language's functional aspects are constructed and explained through sociological features. In social relations, the influence of hegemony and power are focused on linguistic features. Through the use of language's lens, the abuse of power and hegemonic attitudes is analyzed by $\mathrm{CDA}$. The discourse dimension and context are analyzed later.

\section{Research Methodology}

The data for this project is collected from Shah Mehmood Qureshi's historical speech at UNSC on May 20, 2021. The opening lines of speech that "what we do today, or cannot do, will be recorded in history. Fairclough 3D model is used to conduct the reach. The research is qualitative and descriptive in nature. This research is qualitative in nature and there is no human subject interaction. While conducting the research it was dealt with carefully when dealing with ethnic consideration. There is no esthetical issue because no interview was taken in the research.

\subsection{Data Collection}

The script of Shah Mehmood Qureshi's (2021) original speech was taken from YouTube, https://www.youtube.com/watch?v=2N_wKAx9Rrc. The speech was delivered in UNGA Session for Palestine at the 67th plenary meeting of the United Nations General Assembly in New York to highlight Israeli atrocities against Palestinians the script of the speech has been taken to aim with doing Critical Discourse Analysis.

\section{Discussion and Analysis}

The data (Speech) has been collected from YouTube by the researcher and the Fairclough 3D model has been used to interpret and analyze the data. By following this model, we can analyze the speech's additional values, expressiveness, and relational aspects. The speech contains 32 lines and 266 words. The whole text of the speech is analyzed critically at the micro and macro level through three aspects. The text deals with the linguistic choice analysis, the discourse practices that deal with the background of that specific text, and specifically the political-economic and social levels that come under socio-cultural practices... The sociocultural perspective of the text describes the discursive practices like discrimination, racism social inequality which is revealed through analysis of the text. In nature, it is explanatory and critical. All aspects are considered systematically by the Fairclough approach. In specifying text the linguistic features are provided with a description at the first level. At the second level, the interaction like a particular text relation is interpreted. And at the third stage, the socio-political variable at the broader level and their interaction with them are explained.

\subsection{Text Analysis}

In the Fairclough paradigm, the text has taken center stage. Text is regarded as one of the most important foundations in analysis. Text analysis is inextricably tied to people's use of language in any real-world scenario. This method was originally known as 'Critical Language Study.' The study's major focus was on language that deals with knowingly exploitative social relationships. Text analysis takes into account a variety of aesthetic aspects, as well as lexical choices, cohesiveness, and coherence. In comparison to the syntactic level, this analysis has a broader scope. This investigation is further divided into two parts. In the first section, the new and presented information, as well as the theme, rheme within the phrases or clauses, are highlighted and studied. In the second portion, a thematic development focusing on four categories provides a study of the link between clauses and sentences. Theme and Rheme lead to the creation of an informatic structure through a series of new and provided information. The sentences of a speech are structured using an informative structure. It also promotes cohesiveness and coherence. Sentences that are both 
conceptually and grammatically exact are formed by following thematic and informational structures appropriately. Through cohesiveness, the speaker's feelings and message effects are amplified. It offers the speaker authority to leave a deep impression on the listener. The informative structure creates a logical succession in the sentences. The effectiveness of a speech is determined by the new and sequentially presented information. It acts as a link between the speaker and the audience. To keep the conversation together as a whole, Several themes are The magnetism of Mark and Unmark. Speech coherence is developed as a result of the new and provided information. They just have one topic that they obtain from a speaker's speech and then create through cohesiveness and coherence in connected sentences: profanity.

The Constant Theme Pattern is used in speech to establish thematic progression. The chosen speech is well-thought-out as well as well-knit. It's a well-structured speech. A chain has been constructed by keeping his focus on the core concept and employing relevant phrases and related thoughts. Every component is linked to the others. The audience's emotions are not harmed as a result of this strategy. "People are generally and people in Pakistan in particular disappointed at the indecision, lack of consciences, in the Security Council". Its focus is on the UN's duty to play its part in discouraging Israel's violent acts against innocent Palestinians. Only the Constant Theme Pattern was employed throughout the speech, and the other three patterns were not used at all. Through Constant Theme Pattern, the theme or major idea is focused on the audience in order to maintain emotional impact.

He repeated some words throughout his entire speech. This feature stands out in a speech, and it's known as repetition. The usage of the same exact word, phrase, or sentence more than once is referred to as repetition in this scenario. We can locate a point where he employs this device to more forcefully express his message during the study of speech. He said the term "violation" twice more. First, for the world community to condemn Israeli violations of international law, and second, for such violations to be held accountable in front of an international court of justice to be judged as war crimes.

Another device called Parallelism is used to reveal syntactic over-regularity. Parallelism is not the same as repetition. The equivalent places are repeated in parallelism. In simple terms, grammatically equal sentence parts are repeated in a balanced manner. Parallelism is also used by Shah Mehmood Qureshi in his discourse. Parallelism aids in the organization of concepts so that the audience may understand them better." the sentiments of the people of Pakistan and the outrage on the streets of Pakistan..." for example he utilizes metaphor as a stylistic strategy to link a tangible image to an abstract idea. Shah Mehmood Qureshi employed figurative language in his talks. Concrete metaphors were employed in the speech to convey certain contrastive themes as well as to improve the attractiveness of the speech. For example, he uses the word "armed" to describe the incompatible discrimination between Israelis and Palestinians, which symbolizes my country's complete support as well as the entire world's ability to understand the anguish of innocent Palestinians who have been imprisoned for 72 years. He uses the word "silent" in his sentence. When something bad occurs to Muslims, the entire world cries, but when Muslims are suffering, especially in Palestine and Kashmir, everyone remains silent because of Israel, which is dear to America, and India, which is an approaching economic center. He sometimes uses the word "enough" in a figurative sense, implying that the final bounds of tolerance have been reached. Enough for now. Israel must be sanctioned by the United Nations.

\subsection{Analyzing Context}

Shah Mehmood Qureshi's remark is set in a scenario in which Palestinians have no rights in their country. In that region, religious, social, and racial discrimination is at an all-time high. For the past 70 years, Pakistan's foreign minister has raised his voice in support of the innocent people of Gaza who have been subjected to Israel's indiscriminate terror attacks. Israel's discriminating and brutal attitude toward Palestine is unforgivable. This discriminating decision sends a powerful message to the Palestinian people about where the world is headed. When the UNSC intervenes to protect their civil rights, in that region, Muslims are regarded as inferior, religiously, politically, economically, and socially to Christians and Jews. For Palestinian Muslims, this has now become a battle of philosophy and identity. They are fighting for more than simply a piece of land; they are fighting for their identity. As world-famous intellectual Noam Chomsky once tweeted in the favor of the people of Palestine, he wrote that "you take my water, burn my olive trees, destroy my house, take my job, steal my land, imprison my father, kill my mother, bombard my country, starve us all, humiliate us all but I am to blame: I shot a rocket back (Noam Chomsky)" PM Imran Khan retweeted this to show his support for the Palestinian people (Imran Khan, 2021). He pushed for equal rights in the two-state solution so that Palestinians might live normal lives and exercise their fundamental rights. They are treated as second-class citizens by Jews in all aspects of life, and as a result, they are exploited by Israel. Shah Mehmood Qureshi reminded the UN Security Council that they are human beings living in "Hell on Earth," and that Israel's hegemony and bigotry must end.

\subsection{Analysis of Discourse Practices and Socio-Political Aspect of Speech}

According to Fairclough (1992), two components within sociopolitical aspects are given a lot of weight: discourse practices and cultural perspective. Speech practices refer to the implementation of social processes through discourse. Discourses are socially constructed, and their legitimacy is established. The circumstances that aid discourse construction is also significant because they provide insight into the political and socio-cultural characteristics of a particular discourse. Discourse and socio-political practices 
are investigated in three primary areas: style, genre, and discourse analysis. During the examination of a specific speech, the researcher discusses the relationship between different elements.

Lexical choices are addressed in a full socio-cultural framework of speech. The term "genre analysis" relates to the lexical choices made. Textual analysis is also known as genre analysis. The identification of certain patter is also addressed in the speech. The term "cessation of hostilities" is used in the first paragraph to refer to a conflict that began 73 years ago but has yet to be resolved. Generations have been destroyed on both sides, yet there has never been a single moment of peace to live in., he then utilizes the world to his advantage. The term "silent" alludes to the world's and international organizations' illegal quiet on the death of innocent children, mothers, and other senior citizens who have the right to peacefully live in their homeland. The term "enough" was used in the speech to express the Muslim world's intention that enough is enough today. What is the world waiting for? Israel is breaking international treaties. That country has committed war crimes. They are gradually encroaching on Palestinian land, while the world remains silent as to why. And when will the UN act against Israel, and when will Israel be held accountable for his crimes?

The speaker's style transmits reputation during critical discourse analysis. Relational values and expressiveness are intimately linked in speech analysis. The speaker's own experience is reflected in the expressive values he uses. The speaker is a Muslim who has faced similar situations in his nation during the fight against terrorism. He is well-versed in the current state of the PalestinianIsraeli conflict. Relational values are used to characterize the relationship between the audience and the speaker. Using phrases like "humanitarian," he evoked the audience so that they could feel the agony of those who are suffering and take action to help them. He uses the words "I," "my," and "me" several times in his address, referring to himself as the representative of the Muslim community in Palestine and around the world. When he says "my," he's referring to Pakistan's concerns about the current situation in Palestine, and when he says "my," he's referring to Pakistani Prime Minister Nawaz Sharif's objectives about the issue. With the use of word choices, the speaker became immersed in the oppressed one sentiment.

The representational values are given a lot of weight. Representational value shapes the audience's worldview. Representational values suggest a specific socio-cultural backdrop and discussion of topic matter through speech. What makes this speech so distinctive and essential, and how does it differ from other speeches, is the fundamental question that arises here. This speech stands out because of its background, history, and context, which set it apart from others. The political and social framework revolves around the central theme of increased economic and political disparities between Palestinians and Israelis. Shah Mehmood chastised the UN for failing to take appropriate measures at the appropriate time. He also chastised the UN for failing to keep his pledge to write its charter and include it in its constitution. Palestinians are unable to realize their basic rights, such as freedom, social equality, and political equality, in their homeland. The UN must carry out its decision in accordance with Resolution 242, which says that Israel shall withdraw its armed forces to their pre- 1967 positions

\section{Conclusion and Recommendations}

The research paradigms are interpretative in nature for analysis of the data and this is linked with the limitation of the study. Because it is difficult to analyze the whole speech of Shah Mehmood Qureshi only the first half has been taken, it is difficult to interpret and analyze the chunk of speech perfectly. To gain a specific purpose in speech, he used different devices like textual and stylistic to give his ideology more explicatively. The sophisticated manners of ideology are propagated through the speech with all its prerequisites. It was well organized syntactically and produces its thematic message that was based on religious sociocultural and political discrimination and biased as well as inequality in cohesion. The expressive speaker values and relational indications were ordered according to the situation. This phenomenon helped recapitulate the background. The relation of powerful and oppressed was highlighted with the help of different devices like metaphors successively as well as impressively. The strength and support were achieved very successively and persuasively and also, there was no conflict with the powerful the inequalities in social institutions were highlighted very peacefully in the speech. For further research on the speech, other factors like culture, media representation, and social cognition could be used. While conserving the same pattern, CDA has multiple approaches for application in different ways. The Wodak and VanDijk proposed models in qualitative research could be applied.

\section{References}

[1] Blommaert, J. (2005). Discourse. A critical introduction. Cambridge: Cambridge University Press

[2] Brown, G. and Yule, G. (1985). Discourse Analysis. Cambridge: Cambridge University Press 
[3] Carroll, W. (2004). Critical Strategies/or Social Research. Toronto, Ontario: Canadian Scholars' Press Inc.

[4] Chilton, P. (1996). Security metaphors: Cold war discourse from containment to common house. New York: Peter Lang.

[5] Corson, D. (1995). Discourse and Power in Educational Organizations, Cresskill: Hampton Press, N.J.

[6] Fairclough, N. L. (1989). Language and power. London: Longman Press.

[7] Fairclough, N. (1992). Discourse and social change. Cambridge: Polity Press

[8] Fairclough, N. (1992) Discourse and social change. London: Polity Press

[9] Fairclough, N. (1995a). Critical discourse analysis: The critical study of language. London: Longman.

[10] Fairclough, N. (1995b). Media Discourse. London: Edward Arnold.

[11] Fowler, R. (1996). 'On Critical Linguistics 1': in Caldas-Coulthard, C. R. and Coulthard, M.(eds.) Texts and Practices: Readings in Critical Discourse Analysis, London: Routledge.

[12] Gee, J. P. (1990). Social linguistics and literacies: Ideology in discourses. London: The Falmer Press

[13] Halliday, M. A. K. (1978). Language and Social Semiotics. London: Edward Arnold

[14] Jorgensen, M \& Phillips, L. (2002). Discourse analysis as theory and method. London: Sage Publications

[15] Halliday, M. A. K. (1979). Linguistic function and literary style: an inquiry into the language of William Golding"s The Inheritors. In Linguistic Studies of Text and Discourse. ed. Jonathan J.Webster. 88-125. Peking: Peking University Press.

[16] Hu Z. (1988). A Course of Linguistics. Peking: Peking University Press.

[17] Meyer, M. (2001). Between theory, method, and politics: Positioning of the approaches to CDA. In R. Wodak \& M. Meyer (Ed.), Methods o/Critical Discourse Analysis

[18] Sampson, G. (1980) School of Linguistics: Competition and Evaluation. London: Longman

[19] Titscher, S.; Meyer, M.; Wodak, R.; \& Vetter, E. (2000) Methods of text and discourse analysis. London: Sage.

[20] Van Dijk, T.A. (1991). Racism and the press. London: Routledge

[21] Van Dijk, TA. (1993). Elite discourse and racism. London: Sage Publications. pp. (242-282)

[22] VanDijk, T.A. (1998a). Critical discourse analysis. Available: http://www.hum.uva.nl/teun/cda.htm. (1/25/2000)

[23] Wodak, R. (2001). What CDA is about - a summary of its history, important concepts, and its developments. In R. Wodak \& M. Meyer (Ed.). Methods of critical discourse analysis. London - Thousand Oaks - New Delhi: Sage Publications 